\title{
Malignant Gastric Germ Cell Tumor
}

National Cancer Institute

\section{Source}

National Cancer Institute. Malignant Gastric Germ Cell Tumor. NCI Thesaurus. Code C5486.

A malignant germ cell tumor that arises from the stomach. It includes choriocarcinoma and immature teratoma. 